\title{
New Derivatives of GnRH as Potential Anticancer Therapeutic Agents
}

\author{
Gábor Mezö', Marilena Manea ${ }^{2}$, Ildikó Szabó' ${ }^{1}$ Borbála Vincze ${ }^{3}$ and Magdolna Kovács*.4

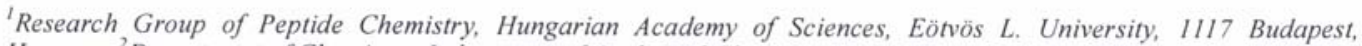 \\ Hungary, ${ }^{2}$ Department of Chemistry, Laboratory of Analytical Chemistry and Biopolymer Structure Analysis, University \\ of Konstanz, 78457 Konstanz, Germany, ${ }^{3}$ Department of Biochemistry, National Institute of Oncology, 1122 Budapest, \\ Hungary and Department of Anatomy, University of Pécs, Medical School, 7624 Pécs, Hungary
}

Abstract: GnRH (gonadotropin-releasing hormone), a decapeptide produced by the hypothalamus, plays an important role in the reproduction by regulating the pituitary-gonadal axis. Continuous high doses of GnRH or its superactive agonists result in desensitization of the pituitary gonadotropes and a suppression of sex steroid production by the gonads (chemical castration). Based on these effects, the treatment with GnRH agonists has become a widely used hormonal therapy of the sex-steroid dependent tumors. It was also demonstrated that most tumor cells contain GnRH receptors, and the direct antiproliferative effect of $\mathrm{GnRH}$ analogs on cancer cells might be mediated by these receptors. Development of new GnRH derivatives is focused on the decrease of their hormonal potency resulting in higher selectivity of the antitumor activity. One of the most promising natural GnRH analogs, lamprey (I) IGnRH-III, was isolated from see lamprey. This variant of $\mathrm{GnRH}$ binds to GnRH receptors and inhibits proliferation of various cancer cells. However, its endocrine effect is insignificant in mammals. IGnRH-III dimers and conjugates were prepared and were shown to have increased antiproliferative effects on various cancer cells, while their hormonal activity was lower than that of the native hormone. IGnRH-III was applied as targeting moiety to deliver anticancer agents to tumor cells. Research data concerning IGnRH-III and its analogs represent a new outlook for research trends of the application of GnRH compounds in cancer chemotherapy. Studies on the effects of IGnRH-III derivatives including antiproliferative effects, cytotoxicity, hormonal actions, and enzymatic stability are reviewed in this article.

Keywords: Gonadotropin releasing hormone $(\mathrm{GnRH})$, targeted chemotherapy, drug delivery, GnRH receptors, conjugates, dimer derivatives, enzymatic stability.

\section{INTRODUCTION}

Chemotherapy is the main procedure for treatment of advanced or metastatic cancers. This method, however, is restricted by aquired or intrinsic multidrug resistance of cancer cells, the lack of selectivity, fast elimination of drugs from the blood circulation, and toxic side effects resulting from high doses required for the therapeutic efficiency [1]. In recent years, cancer research has turned to a more selective, targeted approach, that produced anticancer therapies with improved efficacy and fewer side effects. Receptors for peptide hormones, such as gonadotropinreleasing hormone $(\mathrm{GnRH})$, somatostatin, bombesin, and others, are expressed on tumor cells in high concentration and serve as targets for peptide ligands that can be linked to various cytotoxic agents [2,3]. Consequently, peptide hormones or hormone analogs can be used as carriers to deliver cytotoxic agents directly to tumor cells, thereby increasing the concentration of the drugs in the tumor tissue and sparing normal cells from unnecessary exposure. One such carrier hormone used for targeted tumor therapy is the mammalian hypothalamic decapeptide GnRH (GnRH also called LHRH; Glp-His-Trp-Ser-Tyr-Gly-Leu-Arg-Pro-Gly$\mathrm{NH}_{2}$ ) [1-5]. However, because the endocrine effects of hormone molecules are not always favorable for tumor therapy, development of new GnRH derivatives is focused on the decrease of their hormonal potency and the increase of the antitumor activity [6-8]. The most promising natural GnRH analog is lamprey IGnRH-III (Glp-His-Trp-Ser-His-Asp-

*Address correspondance to this author at the Department of Anatomy, Medical School, University of Pécs, 12 Szigeti Str., 7624 Pécs, Hungary, Tel: +36-(72)536-001; Fax: +36(72)536-393;

E-mail: magdolna.kovacs@aok.pte.hu
Trp-Lys-Pro-Gly- $\mathrm{NH}_{2}$ ), which binds to both type I and type II GnRH receptors (GnRH-IR and GnRH-IIR) [9]. This variant of $\mathrm{GnRH}$ inhibits the proliferation of various cancer cells but its hormonal activity on gonadotropin release is insignificant in mammals [10-12]. Therefore, IGnRH-III and its analogs represent a new outlook for the research trends of application of GnRH compounds in cancer therapy.

In this paper we review the research trends of the 21 st century in targeted chemotherapy using GnRH derivatives, which serve as targeting moieties of cytotoxic conjugates to tumors and also as antiproliferative agents themselves.

\section{Endocrine Actions of GnRH Peptides}

Two forms of GnRH are present in humans. The wellknown mammalian $\mathrm{GnRH}$ type I $(\mathrm{GnRH})$ plays a pivotal role in the control of reproduction by stimulating the secretion of pituitary luteinising hormone (LH) and follicle stimulating hormone (FSH) and thereby controls gametogenesis and sex steroid hormone secretion of the gonads [1-4,13]. GnRH type II (Glp-His-Trp-Ser-His-Gly-Trp-Tyr-Pro-Gly-NH ; GnRH-II) appears to be a neuromodulator and stimulates sexual behavior [14]. GnRH-II was originally isolated from chicken hypothalamus (cGnRH-II) and was found to be universally present and conserved from bony fish to human [15]. The amino acid sequence of GnRH-II has $70 \%$ homology to GnRH but a different gene encodes the receptor protein. GnRH-Il is expressed at significantly higher levels outside than inside the brain, especially in kidney, bone marrow, and prostate, though its function has not yet been elucidated [16].

The effects of GnRH are mediated by high-affinity G protein-coupled receptors found primarily on pituitary gonadotrophs and in various extrapituitary sites as well $[17,18]$. 
Responses to GnRH vary under different conditions and depend on the regimens of administration and the doses delivered to gonadotroph cells. Sustained administration of GnRH or its potent agonistic analogs, such as triptorelin, leuprolide, goserelin, or buserelin, leads to desensitization of gonadotrophs and down-regulation of the pituitary GnRH receptors, resulting in the suppression of circulating levels of gonadotropins and sex steroids [4,18-21]. In the past 30 years more than $3000 \mathrm{GnRH}$ derivatives were prepared, and many agonists found important clinical applications in gynecology and oncology. Potent GnRH antagonists were also developed, and some of them such as Cetrorelix, Ganirelix, and Abarelix have been introduced in the clinical practice. These competitive antagonists of GnRH cause an immediate inhibition of sex steroid secretion and a reversible chemical castration after chronic administration [22,23]. The prolonged sex hormone deprivation induced by chronic tretament with $\mathrm{GnRH}$ analogs can be beneficial for sex hormone-dependent tumors, such as estrogen-dependent breast and androgen-dependent prostate cancers [18-20].

\section{GnRH Receptors in Tumor Tissues}

The actions of GnRH in pituitary and extrapituitary tissues are mediated by type I GnRH receptor. GnRH-IR is a member of the 7-transmembrane G-protein-coupled receptor (GPCR) family $[24,25]$. The receptor protein consists of 329 amino acids and has no C-terminal cytoplasmic tail [15]. Due to the lack of the cytoplasmic tail, they do not bind to arrestins or signal via arrestins. In addition, they do not desensitize rapidly and internalize slowly [26]. This wellcharacterized GnRH-IR is activated preferentially by $\mathrm{GnRH}$ and mediates the hypothalamic control of mammalian reproduction.

GnRH-IR is also expressed in several tumor cells and may mediate the anti-cancer effect of $\mathrm{GnRH}$ analogs $[15,27]$. GnRH-IRs on tumors correspond to pituitary receptors in terms of mRNA sequence and the molecular mass of protein, but tumoral $\mathrm{GnRH}$ receptors display a different pharmacological prefile. It was demonstrated that the nucleotide sequence of GnRH-IRs in human ovarian tumors is identical with that in pituitary, and about $80 \%$ of ovarian and endometrial cancers express high affinity binding sites for GnRH [28-30]. The presence of GnRH-IR was also observed in normal breast tissue [29].

The basic mechanism of action of GnRH analogs on cancer cells was initially assumed to be indirect through the supression of sex steroids [17-20]. However, the antiproliferative action of $\mathrm{GnRH}$ analogs on various human cancer cell lines suggested that they also exert a direct effect mediated by tumoral GnRH receptors. Interest in these extrapituitary $\mathrm{GnRH}$ receptors originates primarily from the fact that GnRH analogs or their cytotoxic derivatives can inhibit cancer cell proliferation, and direct antiproliferative effects may therefore contribute to the therapeutic effects of GnRH analogs in cancer treatment $[1-5,17-20,26]$. Specific binding sites for GnRH were first reported on breast cancers and later also on endometrial, ovarian and prostatic cancers $[28,31-35]$. The mRNA expression of the GnRH receptor gene in these cancers has also been demonstrated [28,35-38]. About $50-64 \%$ of human breast cancers express GnRH-IR
[34-35,39], and mRNA for the receptor was also detected in a normal breast fragment adjacent to ductal carcinoma [40]. Expression of mRNA and protein for GnRH-IR was found in androgen-dependent LNCaP and androgen-independent DU 145 prostate cancer cell lines [41]. In yet, Straub et al. reported that $100 \%$ of hormone refractory prostate cancer specimens express mRNA for GnRH receptor [37]. The incidence of $\mathrm{GnRH}$ receptor expression in various human cancer specimens has expertly been reviewed [38]. In addition to breast, ovarian, endometrial and prostatic tumors, cancer specimens from some non-reproductive organs were also shown to express receptors for GnRH [38]. These specimens include oral and laryngeal cancers, renal carcinomas, brain tumors, melanomas, liver, pancreatic, colon carcinomas, and non-Hodgkin lymphomas [38].

Although the expression of GnRH-IR gene and cellsurface GnRH binding sites is lower in tumor tissues than in pituitary, the GnRH-IR effectively mediates the inhibitory effect of $\mathrm{GnRH}$ analogs on cell proliferation. One explanation is that GnRH-IR is resistant to desensitization and undergoes very slow internalization. Therefore, it is believed that GnRH-IR remains active at the cell surface for longer than other GPCRs. There are evidences that G-protein coupling can be GnRH-concentration dependent [42]. It is hypothesized that $\mathrm{GnRH}$ analogs applied in $\mu \mathrm{mol}$ concentration bind to the receptor persistently and can inhibit cell proliferation through various signal transduction pathways [42]. In contrast to tumor cells, GnRH receptors are not present on most normal tissues or expressed only in low levels in some healthy organs including prostate, testis, and ovary $[43,44]$. This difference between normal and cancer cells makes $\mathrm{GnRH}$ receptors a distinct target for cancer therapy.

\section{Signal Transduction Pathway Mediated by GnRH-IR}

The signal transduction mechanisms mediated by GnRH$\mathrm{R}$ on tumor cells differ from the classical GnRH-R signals known to operate in the pituitary $[30,45,46]$. Ligand-receptor interactions and receptor conformational changes of $\mathrm{GnRH}$ IR exist in cancer cells, which are selective for GnRH analogs and their intracellular signaling pathways Fig. (1) $[47,48]$. The intracellular signal induced by $\mathrm{GnRH}$ analogs depends on cell type and nature of the ligand, called "ligand induced-selective-signaling" $[14,48,49]$. In cancer cells, GnRH-IR couples to multiple G proteins, and the antiproliferative signal transduction is mediated through $\mathrm{G}$ protein $\alpha \mathrm{i}$. Binding of a GnRH analog to receptors on tumor cells can initiate a series of intracellular events involving c-Src, c-Jun $\mathrm{N}$-terminal kinase (JNK) and p38 stress activated kinases $[46,48]$. It can also interact with mitogenic signal transduction pathways of growth factor receptors, such as epidermal growth factor (EGF) and insulin-like growth factor-I (IGF-1) receptor, and can block the growth-promoting action of estradiol (E2) [45,50-52]. GnRH analogs down-regulate growth factor actions by decreasing the expression of growth factors and their receptors, activate phosphotyrosine phosphatase and inhibit Akt (Fig. (1)) [46,48,53-55]. GnRH analogs completely blocked the EGF-induced activation of mitogen-activated protein kinase (MAPK) and the expression of the immediate early gene c-fos [51,52].

Putting results together, GnRH signaling cross-attenuate growth factor signaling to limit tumor growth. According to 


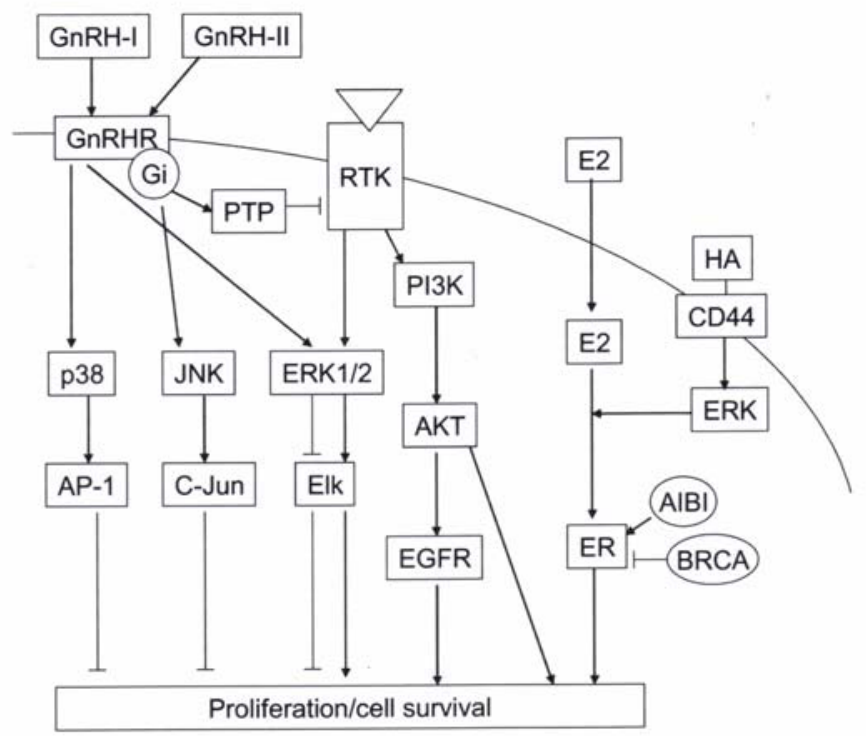

Fig. (1). Schematic representation of signaling pathways of GnRH-I,II in cancer cells [46]. Gi, G-protein ai; PTP, phosphotyrosine phosphatase; RTK, receptor tyrosine kinase; PI3K, phosphoinositide 3 kinase; E2, estradiol; ER, estrogen receptor; HA, hyaluronan; JNK, c-Jun Nterminal kinase; AP-1, activator protein-1; ERK 1/2, extracellular signal-regulated kinases 1 and 2; EGFR, epidermal growth factor receptor.

recent results, GnRH also regulates cell motility through its interaction with the small GTPases Racl, Cdc42, and RhoA, which are involved in the regulation of actin polymerization [56]. These actions result in the inhibition of cell proliferation, as indicated by increased $\mathrm{G} 0 / 1$ phase of cell cycle and decreased DNA synthesis [30,57].

\section{The Putative type-II GnRH Receptor in Tumor Tissues}

Different forms of $\mathrm{GnRH}$ receptors mediate the actions of GnRH and GnRH-II. The gene for type II GnRH receptor (GnRH-RII) was characterized in nonhuman primates, such as marmoset monkey, rhesus monkey, and African green monkey, and in amphibian as well [58-61]. mRNA expression of primate GnRH-IIR has also been described in human tissues [59]. The amino acid sequence of type II receptor has $68 \%$ homology ( $40 \%$ identity) to GnRH-IR. Type II receptors are preferentially activated by GnRH-II and do have Cterminal tails of various length. They bind to arrestins, signal via arrestin, and undergo rapid and arrestin-dependent internalization and desensitization [61].

Expression of mRNAs for GnRH-II and GnRH-IIR occur in reproductive tissues and their tumors, such as endometrial, ovarian, and breast tumors, and in prostate cancer cell lines as well [14,62-65]. The functional GnRH-IIR is expressed in various splice variants, but the human type-II receptor gene homolog carries a frame shift mutation and a premature stop codon. This observation indicates that a conventional receptor system and the full-length receptor are absent in humans [65]. Although the expression of a functional human type II GnRH-R remains controversial, it is becoming evident that responses specific for GnRH-II can be observed in certain human cell types.

\section{Antiproliferative Effects Mediated by GnRH-IIR}

Several studies demonstrated the antiproliferative effects of GnRH-I and/or GnRH-II analogs in different human cancer cell lines (Table 1). It was shown in human endometrial and ovarian cancer cell lines that GnRH-II and its agonists cause significantly greater inhibition of cell proliferation than GnRH-I agonists [27,66-69]. The antiproliferative effect of GnRH-II analogs, similarly to GnRH analogs, is mediated through an interaction with growth factor-induced mitogenic signals $[70,71]$. The GnRH-II signaling mechanisms are poorly understood. It is still unsolved whether GnRH-IR mediates the effect of both GnRH and GnRH-II. Cotreatment with GnRH-I antagonist Antide and GnRH or GnRH-II of ovarian cancer cells resulted in prevention of both GnRH- and GnRH-II-induced antiproliferation [72]. These observations indicate that the GnRH-IR mediates the antiproliferative effects of both GnRH and GnRH-II. However, other results support the hypothesis that the antiproliferative effect of GnRH-II is mediated through distinct receptors that are specific for GnRH-II. After the knockout of GnRH-IR in endometrial and ovarian cancer cells, the antiproliferative effect of $\mathrm{GnRH}$ agonist triptorelin was abrogated, while the growth-inhibitory effect of GnRH antagonist Cetrorelix and GnRH-II persisted [27].

It has been reported that application of GnRH-II antagonists in ovarian and endometrial cancer cell lines resulted in apoptotic cell death via dose-dependent activation of caspase- 3 and reduction of cell proliferation [45]. However, induction of apoptosis was not involved in the antiproliferative effects of the agonists of GnRH or GnRH-II [70]. High concentration of GnRH-II antagonist triptorelix-1 but not $\mathrm{GnRH}$ antagonist Cetrorelix induced cancer cell death in 
Table 1. Antiproliferative Effects of GnRH Analogs on Human Cancer Cell Lines

\begin{tabular}{|c|c|c|c|c|c|c|}
\hline \multirow[t]{2}{*}{ Cancer Cell Lines } & \multirow{2}{*}{ Expression of GnRH-IR } & \multicolumn{2}{|c|}{$\begin{array}{c}\text { Antiproliferative Effects of GnRH-I } \\
\text { Analogs }\end{array}$} & \multicolumn{2}{|c|}{$\begin{array}{l}\text { Antiproliferative Effects of GnRH-II } \\
\text { Analogs }\end{array}$} & \multirow[t]{2}{*}{ Ref. } \\
\hline & & Agonists & Antagonists & Agonists & Antagonists & \\
\hline \multicolumn{7}{|l|}{ Ovarian } \\
\hline EFO-21 & + & + & + & + & + & {$[28,45,66]$} \\
\hline $\mathrm{EFO}-27$ & + & + & - & + & & {$[28,66]$} \\
\hline Ovcar-3 & + & + & + & & + & {$[28,45,66]$} \\
\hline SK-OV-3 & - & - & + & + & + & {$[28,45,66]$} \\
\hline \multicolumn{7}{|l|}{ Endometrial } \\
\hline Ishikawa & + & + & + & + & + & {$[28,45,66]$} \\
\hline Hec-1A & + & + & + & + & + & {$[28,45,66]$} \\
\hline Hec-1B & + & + & + & + & & {$[28,66]$} \\
\hline \multicolumn{7}{|l|}{ Prostate } \\
\hline DU-145 & + & + & + & & & [67] \\
\hline PC-82 & + & + & & & & {$[68]$} \\
\hline LNCaP & + & + & & & & [41] \\
\hline \multicolumn{7}{|l|}{ Breast } \\
\hline MCF-7 & + & + & + & + & & {$[11,64]$} \\
\hline T47-D & + & + & & + & & [64] \\
\hline
\end{tabular}

vitro, probably through an apoptotic process. These observations show that GnRH-IIRs may play a role in this mechanism. However, it remains to be solved whether GnRH-II antagonists induce apoptosis via the GnRH-I or GnRH-Il receptor.

In conclusion, both GnRH and GnRH-II play an important role in the regulation of cell proliferation [71]. The presence of specific receptors for GnRH and GnRH-II in cancer tissues might represent a new molecular target for the clinical application of these compounds in oncology. Experimental results indicate that agonists and antagonists of $\mathrm{GnRH}$ and GnRH-II bind to these receptors and cause a significant inhibition of cell proliferation and metastatic behavior of tumors. Investigation and understanding of receptor counteracting and signaling mechanisms induced by $\mathrm{GnRH}$ and GnRH-II analogs make possible the development of new tumor-selective compounds.

\section{GnRH Analogs as Targeting Moieties}

Clinical studies of GnRH analogs have shown that the duration of remission of tumor growth may be limited, as hormonal manipulations do not prevent the ultimate tumor growth of hormone-independent cells [73]. A combination of hormonal therapy with chemotherapy might improve the efficacy of the medication and prolong survival [74]. Moreover, the covalent attachment of drug molecules to hormonal peptides, instead of their physical mixing, may also result in enhanced antitumor activity and increased selectivity.

The modern oncological strategy of targeted chemotherapy using GnRH derivatives for increasing the drug selectiv- ity in cancer therapy was designed in A.V. Schally's laboratory to improve the effectiveness of cytotoxic drugs and decrease their peripheral toxicity [75]. The concept is based on the presence of high affinity binding sites for GnRH on various tumor cells. In contrast, the limited number of $\mathrm{GnRH}$ receptors in normal tissues allows binding of cytotoxic drugGnRH conjugates mainly to cancerous cells, avoiding the side effects of non-targeted cytotoxic radicals [38].

The first attempts of cytotoxic drug development are summarized in Table 2. Different antitumor agents, such as D-melphalan, cisplatin, doxorubicin, methotrexate, and (2hydroxymethyl)anthraquinone, were attached to [D-Lys ${ }^{6}$ $\mathrm{GnRH}$ or [D-Orn $\left.{ }^{6}\right]-\mathrm{GnRH}$, in which the side chains of Damino acids served as conjugation sites [76-79]. In some $\mathrm{GnRH}$ derivatives, D-melphalan was incorporated in the sequence at position 6 [75], and various antagonistic analogs of $\mathrm{GnRH}$ were also applied as carriers. The availability of cytotoxic compounds linked to $\mathrm{GnRH}$ analogs could have significant therapeutic importance by targeting cytotoxic drugs to certain tumors possessing receptors for GnRH. However, many of these compounds have only theoretical interest because of their enhanced endocrine effects that might cause unwanted side effects in tumor therapy. The agonists containing cytotoxic radicals induced 10-130 fold $\mathrm{LH}$ release compared to $\mathrm{GnRH}$, while the antagonists blocked ovulation at the applied doses.

The moderate antitumor activity of Dox-GnRH conjugates, in which the amino sugar moiety is attached to a GnRH analog through glutaric acid spacer, and the significant inhibitory effect on tumor growth of HMAQG analogs in which the cytotoxic compound is linked to GnRH derivatives by ester bond prompted the scientists to prepare conju- 
Table 2. Early Attempis for Development of Cytotoxic GnRH Analog Conjugates

\begin{tabular}{|c|c|c|c|c|c|}
\hline GnRH Agonist & GnRH Antagonist & Drug & Bond & Tumor Cells & Ref. \\
\hline GnRH & 1 & D-Mel & D-Mel ${ }^{6}$ incorporation & $\begin{array}{l}\text { T-47D; h breast } \\
\text { MT-4 and MT- } 5 \text {; } \\
\text { rat mammary }\end{array}$ & [75] \\
\hline $\begin{array}{l}\text { D- } \text { Lys }^{6}\left(\mathrm{~A}_{2} \mathrm{pr}\right)-\mathrm{GnRH} \\
\mathrm{D}-\mathrm{Lys}^{6}\left(\mathrm{~A}_{2} \mathrm{bu}\right)-\mathrm{G} R \mathrm{RH}\end{array}$ & 2 & $\begin{array}{l}\mathrm{PtCl}_{2} \text {, bis(salicyliden- } \\
\text { eiminato }) \mathrm{Cu}(\mathrm{II})\end{array}$ & $\begin{array}{l}\text { complex } \\
\text { complex }\end{array}$ & $\begin{array}{l}\text { T-47D; h breast } \\
\text { PC-3; h prostate }\end{array}$ & [76] \\
\hline $\begin{array}{l}\text { D-Lys }{ }^{6}-\mathrm{GnRH} \\
\text { D-Orn }-\mathrm{GnRH} \\
\text { D-Lys }{ }^{6}\left(\mathrm{~A}_{2} \mathrm{pr}\right)-\mathrm{GnRH} \\
\text { D-Orn }\left(\mathrm{A}_{2} \mathrm{pr}\right)-\mathrm{GnRH}\end{array}$ & $1,2,3,4$ & $\begin{array}{l}\text { D-Mel } \\
\text { CPC } \\
\text { HMAQ } \\
\text { Mtx } \\
\text { Dox }\end{array}$ & $\begin{array}{l}\text { amide } \\
\text { amide } \\
\text { ester (through glutaric acid) } \\
\text { amide ( } \gamma \text {-carboxylic group) } \\
\text { amide (aminosugar moiety } \\
\quad \text { through glutaric acid) }\end{array}$ & $\begin{array}{l}\text { SKBr- } 3 ; \mathrm{h} \text { breast } \\
\text { MDA-MB-231; } \mathrm{h} \text { breast } \\
\text { T-47D; } \mathrm{h} \text { breast } \\
\text { MCF-7; } \mathrm{h} \text { breast } \\
\text { PC-3; h prostate } \\
\text { LNCaP; h prostate }\end{array}$ & $\begin{array}{l}{[77]} \\
{[78]}\end{array}$ \\
\hline $\begin{array}{l}\text { D-Lys }{ }^{6}-\mathrm{GnRH}(\mathrm{Ac3}-9 \mathrm{EA}) \\
\text { D-Orn }{ }^{6}-\mathrm{GnRH}(\mathrm{Ac} 3-9 \mathrm{EA}) \\
\text { D-Lys }{ }^{6}-\mathrm{GnRH}(\mathrm{Ac4}-9 \mathrm{EA}) \\
\text { D-Orn }-\mathrm{GnRH}(\mathrm{Ac4}-9 \mathrm{EA})\end{array}$ & & $\begin{array}{l}\text { D-Mel } \\
\text { HMAQ } \\
\text { Mtx } \\
\text { Dox }\end{array}$ & $\begin{array}{l}\text { amide } \\
\text { ester (through glutaric acid) } \\
\text { amide ( } \gamma \text {-carboxylic group) } \\
\text { amide (aminosugar moiety } \\
\quad \text { through glutaric acid) }\end{array}$ & $\begin{array}{l}\text { MCF-7; } h \text { breast } \\
\text { Dunning rat prostate }\end{array}$ & [79] \\
\hline
\end{tabular}

gates containing ester linkage between Dox and GnRH carrier. Schally and his coworkers developed a new series of targeted cytotoxic GnRH analogs by the middle of 1990s. Dox or its highly potent derivative 2-pyrrolino-Dox (AN$201)$ were conjugated to [D-Lys $\left.{ }^{6}\right]-G n R H$ agonist (AN-152 or $\mathrm{AN}-207$, respectively) or to Ac-D-Nal(2)-D-Phe(pCl)-D$\mathrm{Pal}(3)$-Ser-Tyr-D-Lys-Leu-Arg-Pro-D-Ala- $\mathrm{NH}_{2}$ antagonist $[80,81]$. The $14-O$-hemiglutarate derivatives of the drug molecules were attached to the side chain of D-Lys ${ }^{6}$ in the $\mathrm{GnRH}$ analogs, resulting in ester bond between the cytotoxic drug and the carrier peptide. The antitumor activity of AN152 and $\mathrm{AN}-207$ was studied in vitro and in vivo on different types of tumors, such as breast, epithelial, ovarian, endometrial and prostatic cancers, non-Hodgkin's lymphomas and melanomas $[1,3,38,82,83]$. The effect of the compounds depended on the type of cancer cells due to a different density of GnRH-Rs on the cell membranes. In most cases, AN207 , having the stronger drug pyrrolino-Dox, showed higher anticancer activity than AN-152. However, because the pharmaceutical properties of Dox but not of pyrrolino-Dox were well known, the conjugate $\mathrm{AN}-152$ has been investigated in preclinical and clinical studies. A broad spectrum of biological assays was developed for these studies. The investigations confirmed the receptor-mediated uptake of the conjugate. The active drug molecule can be liberated from the conjugate by carboxylesterase enzymes (CE) possibly in the tumor cells. However, it was observed that in serum of nude mice used as model animals $\mathrm{CE}$ had about 10 times higher activity than in humans [84]. The higher CE activity resulted in faster decomposition of the conjugate in mouse than in human serum and the tolerated amount of conjugates was lower in mice [85]. Currently, AN-152 is in phase III clinical trials.

\section{GnRH Conjugates for Photodynamic Therapy}

Photodynamic therapy uses a combination of light, oxigen, and a photosensitizer to damage malignant cells. Rahimipour et al. applied [D-Lys ${ }^{6}$ ]-GnRH agonist and [D$\left.\mathrm{Glp}^{1}, \mathrm{D}-\mathrm{Phe}^{2}, \mathrm{D}-\mathrm{Trp}^{3}, \mathrm{D}-\mathrm{Lys}^{6}\right]$-GnRH antagonist to increase the selectivity of protoporphyrin IX (PpIX) as photosensitizer for photodynamic therapy [86]. Protoporphyrin IX was attached to the $\varepsilon$-amino group of D-Lys in both GnRH analogs via amide bond formation. In vivo, the conjugate (GlpHis-Trp-Ser-Tyr-D-Lys(PpIX)-Leu-Arg-Pro-Gly-NH $\mathrm{NH}_{2}$ had lower potency on LH release than [D-Lys $\left.{ }^{6}\right]-\mathrm{GnRH}$ but its effect was more protracted, suggesting that pharmacokinetics of the GnRH conjugates differ from those of the parent peptides. The conjugates bound to GnRH receptors with lower affinity than the parent peptides, but their receptor-mediated phototoxicity could be demonstrated on $\alpha \mathrm{T} 3-1$ pituitary gonadotrope cell line [87]. The unconjugated $\mathrm{PpIX}$ damaged all types of pituitary cells, while the GnRH conjugate showed high selectivity of phototoxicity to pituitary cells having high concentration of $\mathrm{GnRH}$ receptors. It was speculated that cells transfected by GnRH receptor plasmid DNA might have higher receptor concentration on cell membranes that increases the efficacy of the receptor-mediated phototoxicity of the conjugates. This suggests that it might be possible to use gene therapy for treatment of cancer.

\section{GnRH Conjugates Containing Proapoptotic Peptide}

Chemotherapeutic agents may upregulate the cellular antiapoptotic systems. The key player of this antiapoptotic defense is the BCL-2 protein family. This family consists of two groups of proteins: group 1 has proteins that suppress apoptosis if they are overexpressed, and group 2 includes 
proteins able to induce apoptosis $[88,89]$. The latter peptides contain a specific region termed BCL-2 homology domain 3 (BH3), which is responsible for the induction of apoptosis [90]. Therefore, synthetic peptides homologous to $\mathrm{BH} 3$ domain can potentially improve the effect of chemotherapy by suppressing the antiapoptotic activity of BCL-2 family. BCL-2 family causes the so-called non-pump resistance of cancer cells to chemotherapeutic agents. However, the practical use of the $\mathrm{BH} 3$ peptide is limited by its low capability to permeate cell membranes. To overcome this drawback, Daharp et al. conjugated $\mathrm{BH} 3$ peptide to $\mathrm{GnRH}$ as targeting moiety (<EHWSYGLRPGMGQVGRQLAIIGDDINRRY) [91]. Biological effects of the conjugate were studied on GnRH receptor positive A2780 ovarian, MCF-7 breast, and PC-3 prostate cancer cell lines, and on GnRH receptor negative SKOV-3 ovarian cancer cells. A strong exponential correlation was found between the cytotoxicity of GnRHBH3 peptide and the expression of the GnRH-R gene in cancer cells. The receptor-mediated uptake of the conjugate was confirmed by coincubating the cells with free GnRH. $\mathrm{GnRH}$ decreased the cytotoxicity of GnRH-BH3 peptide in a concentration-dependent manner. In human ovarian carcinoma cells the conjugate suppressed the expression of BCL2 and BCL-XL proteins, which play a role in the cellular antiapoptotic defense. Moreover, GnRH-BH3 caused upregulation of expression of the genes encoding caspaseactivity proteins (APAF-1 and SMAC), leading to the appearance of active caspase 9 and apoptosis induction [92]. According to the authors of this study, a combination of GnRH-BH3 peptide with an anticancer drug in one dru delivery system (DDS) might have certain advantages, such as decreasing the amount of expensive peptide by enhancing the cytotoxicity of the whole system [92]. For this purpose, they developed conjugates in which the anticancer agent camptothecin (CPT) was attached to BH3 or [D$\mathrm{Lys}^{6}{ }^{6}$,desGly ${ }^{10}$,Pro-EA]-GnRH through a polyethylene glycol (PEG) polymer [93]. CPT was attached to Gly or Cys derivatives via ester bond, and the amino acid-CPT conjugates were connected to NHS-PEG-VS through amide or thioether bond. The $\varepsilon$-amino group of D-Lys ${ }^{6}$ was applied for the conjugation of $\mathrm{GnRH}$ analog to PEG (GnRH-PEG-CPT), while the $\mathrm{BH} 3$ was elongated by $\mathrm{Cys}$ at the $\mathrm{C}$-terminus to incorporate a conjugation site (CPT-PEG-BH3). PEG increased the solubility and bioavailibility of the conjugates. Both conjugates showed higher cytotoxicity and apoptosis induction than the free CPT or pegylated CPT. GnRH-PEG$\mathrm{CPT}$ conjugate was the most effective compound, indicating that a process more efficient than simple diffusion or direct endocytosis, a receptor-mediated endocytosis, might be responsible for the increased uptake of this DDS. Moreover, in vivo experiments indicated that the treatment of female mice with GnRH-PEG-CPT conjugate did not lead to disturbance of reproductive functions. This shows that the conjugate did not impose pituitary toxicity [94]. The GnRH-PEG-CPT conjugate accumulated in tumor cells but, similarly to the free CPT or PEG-CPT, caused overexpression of BCL-2 and BCL-XL genes and thereby increased the cellular antiapoptotic defence. To overcome this disadvantage, a multifunctional targeted proapoptotic drug delivery system was designed. This system provides simultaneous tumor targeting by a GnRH derivative, cell death induction by the anticance drug CPT, and suppression of cellular antiapoptotic defense by $\mathrm{BH} 3$ peptide. The three components were conjugated to PEG through a branched citric acid spacer that allows simultaneous binding of several copies of different active ingredients to one polymeric carrier [95,96]. In A2780 human ovarian carcinoma cell line, the conjugate containing all four components caused the greatest suppression of BCL-2 and BCL-XL gene expression and the highest cytotoxicity and apoptosis induction, compared to the conjugates without $\mathrm{GnRH}$ and/or $\mathrm{BH} 3$ peptide. Increasing the number of the components on PEG from 1 to 2 resulted in enhanced efficacy. The conjugates also showed antitumor activity on A2780/AD multidrug-resistant human ovarian carcinoma cell line but their efficacy was lower on this cell line.

In conclusion, the synergism among $\mathrm{CPT}, \mathrm{GnRH}$ derivative, and $\mathrm{BH} 3$ peptide combined in one drug delivery system led to higher antitumor activity of the entire multicomponent delivery system compared to the mixture of the conjugates having only three components (CPT-PEG-BH3 and GnRHPEG-CPT).

\section{GnRH-III}

The third isoform of $\mathrm{GnRH}$, isolated from the sea lamprey (Petromyzon marinus), open a new way in cancer therapy using GnRH derivatives [97]. Lamprey GnRH-III (GlpHis-Trp-Ser-His-Asp-Trp-Lys-Pro-Gly- $\mathrm{NH}_{2}$ ) differs in residues 5-8 from human $\mathrm{GnRH}$, and it shows negligible endocrine activity in mammals. The potency of IGnRH-III on LH release is 500-1000 times lower than that of $\mathrm{GnRH}$ $[10,12,22]$. However, IGnRH-III recognizes both the highand low-affinity binding sites of GnRH on cancer cells and causes significant inhibition of cell proliferation of various human cancers. At micromolar doses this decapeptide hormone suppresses cell proliferation of human breast, prostatic, pancreatic, endometrial, and colonic cancers in a dose-dependent manner $[6,8,10,98-100]$. The growthinhibitory effect is specific and direct because IGnRH-III does not have endocrine activity at doses effective for cell proliferation. Specific binding of IGnRH-III to GnRH receptors and significant antitumor effects were demonstrated on both steroid receptor positive and negative cancer cells. Another advantage of IGnRH-III over other GnRH analogs having anticancer activity is that IGnRH-III contains only Lamino acids, which is presumable to avoid undesirable edematogenic activity [101]. These data indicate that the therapeutic use of IGnRH-III has lower risk of complications than the application of $\mathrm{GnRH}$ analogs [10].

To investigate the structure-antitumor relationship of GnRH peptides several analogs of IGnRH-III were synthesized by Mezö et al. [8]. Only a few of them (IGnRH-III-(19)-EA, [ $\left.\varepsilon-N-A c-L y s^{4}\right]-I G n R H-I I I$, and [cyclo( $\left(\mathrm{Asp}^{6}, \mathrm{Lys}^{8}\right)-$ IGnRH-III]) showed similar antitumor activity to the native compound, but none of them was more potent than the native hormone. It was demonstrated that the indol rings of $\operatorname{Trp}^{3,7}$ residues are important for the anticancer effect, and the replacement of $\mathrm{Gly}^{10}$ by D-Ala, Glp ${ }^{1}$ by Ac-D-Trp, or His ${ }^{5}$ by Lys was not well tolerated.

Herédy-Szabó et al. studied the importance of the central region of IGnRH-III in the growth inhibition of breast cancer cells by Ala-scan. They found that the change of either Asp ${ }^{6}$ or $\operatorname{Trp}^{3}$ by Ala led to the complete loss of binding ability of 
the peptide to GnRH receptors on MDA-MB-231 human breast cancer cells. The replacement of $\mathrm{His}^{5}$ by Ala resulted in a compound having lower affinity to receptors than IGnRH-III and no antiproliferative effect. However, the peptide with Lys/Ala mutation in position 8 had significant inhibitory effect on cell growth at $\mu \mathrm{M}$ concentration [99].

A positional scanning peptide library, focused on the variable region (residues 5-8) of the GnRH family, was synthesized. The peptides were analyzed in competitive binding assays, and based on the results six new analogs were designed. The only effective peptide related to the natural sequence was chicken GnRH-II. The synthetic library, however, did not yield a peptide more potent than IGnRH-III [100].

Investigation of the cellular uptake of the analogs by flow cytometry showed that the N-terminal truncated IGnRH-III derivatives labelled with 5(6)-carboxyfluorescein on $\mathrm{Lys}^{8}$ were internalized by HT-29 colonic and MCF-7 breast cancer cells, similarly to the full length IGnRH-III [102].

\section{Conjugation of IGnRH-III to Non-Biodegradable and Biodegradable Carriers}

It was shown that modification of the lysine side chain of IGnRH-III does not lead to the loss of biological activity. Indeed, conjugation of poly $(N$-vinylpyrrolidone-co-maleic acid) through an enzyme labile GFLG tetrapeptide spacer to the lysine side chain of IGnRH-III resulted in enhanced antiproliferative effect compared to free IGnRH-III [6,103-106]. The anticancer action of the conjugate was demonstrated on various cell lines, such as GnRH-IR-positive human breast, prostate, and endometrial cancer cell lines, and on estrogenindependent MDA-MB-231 xenografts implanted into immunosuppressed nude mice $[6,98]$. The conjugate induced significant accumulation of MCF-7 breast cancer cells in the G2/M phase [98]. In experiments using MDA-MB-231 human breast cancer xenografts in nude mice, IGnRH-III had no influence on tumor growth, whereas its conjugate decreased the tumor volume to $57 \%$ of control values, after subcutaneous (s.c.) administration for four weeks [6]. Histological evidences excluded toxic side effects of both free peptide and conjugate in various organs of healthy animals [6]. The high antitumor activity of the conjugate in vitro and in vivo seems to be due to an enhanced binding through supplementary non-biospecific interactions of the peptide carrier with external domains of the receptor and adjacent membrane structures. The conjugation protects the peptide from proteolysis and thus may result in prolonged receptor occupancy. After internalization of the receptor-conjugate complex, the non-biodegradable copolymers exert toxic effects inside the cell.

After per os treatment of nude mice bearing GnRH-IRpositive HT-29 colon tumor xenografts with radionuclide labeled $\left[\left({ }^{3} \mathrm{H}\right)-\mathrm{IGnRH}-\mathrm{III}\right]$ conjugate, a relatively high accumulation of the conjugate could be observed in the tumor, indicating that the conjugate is target specific. Based on these results, we investigated the in vivo efficacy of IGnRHIII and its copolymer conjugate on the inhibition of HT-29 colon carcinoma xenografts in nude mice. Per os treatment of the mice with $I \mathrm{GnRH}-\mathrm{III}$ at $8 \mathrm{mg} / \mathrm{kg}$ daily doses had no

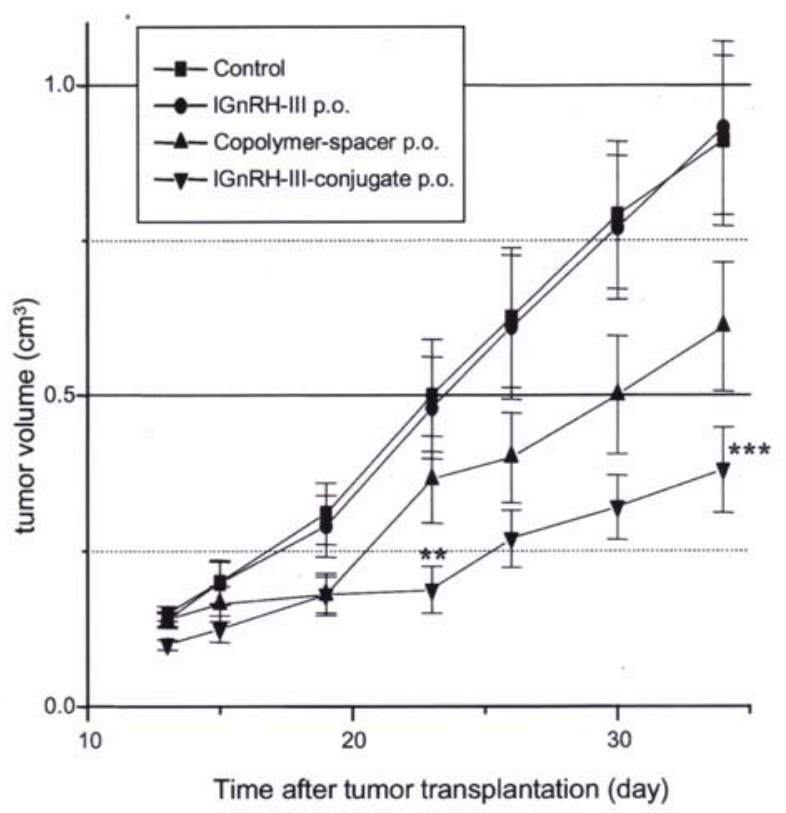

Fig. (2). Effects of per os treatment with IGnRH-III ( $8 \mathrm{mg} / \mathrm{kg}$, once daily; $\bullet$ ), IGnRH-III-conjugate ( $8 \mathrm{mg}$ of conjugated peptide per $\mathrm{kg}$; $\boldsymbol{\nabla}$ or copolymer-spacer ( $57 \mathrm{mg}$ of copolymer-spacer per $\mathrm{kg}$ regarding to the conjugate, $\mathbf{\Delta}$ ) on the volume of HT-29 xenografts in SCID mice, and the tumor volumes of untreated controls $\mathbf{m})$. Results for 7 animals in each group are given as means \pm SD. The data were analyzed by Mann-Whitney test (independent samples) at $95 \%$ confidential interval. $\mathrm{P}^{* *}<0.001 ; \mathrm{P}^{* * *}=0.0006$. 
effect on the growth of tumors, whereas treatment with the conjugate containing $8 \mathrm{mg}$ of conjugated IGnRH-III per $\mathrm{kg}$ body weight significantly decreased tumor volume by the end of treatment for three weeks. The copolymer-spacer caused only a weak inhibition. Follow-up of mice showed that the effect of IGnRH-III-conjugate lasted for more than 3 weeks after terminating the treatment. These results were the first to demonstrate that the non-biodegradable copolymer, $\operatorname{poly}(N$-vinylpyrrolidone-co-maleic acid) contributed to the antitumor effect of IGnRH-III-conjugate (Fig. (2)). The conjugation led to the loss of endocrine activity of IGnRH-III in vitro and in vivo and resulted in a significant increase of the anticancer potency. These findings provide evidences that the slight hormonal activity of IGnRH-III can be destroyed and the anticancer selectivity can be increased by eliminating the basic character at position 8 , which seems to be important for endocrine effect $[6,12]$.

IGnRH-III was also conjugated to a biodegradable branched chain polymeric polypeptide containing a polylysine backbone. Poly[Lys(Ac-Glu $\left.\left.\mathrm{H}_{\mathrm{j}}-\mathrm{Ser}_{\mathrm{i}}-\mathrm{DL}-\mathrm{Ala} \mathrm{a}_{\mathrm{m}}\right)\right]$, a

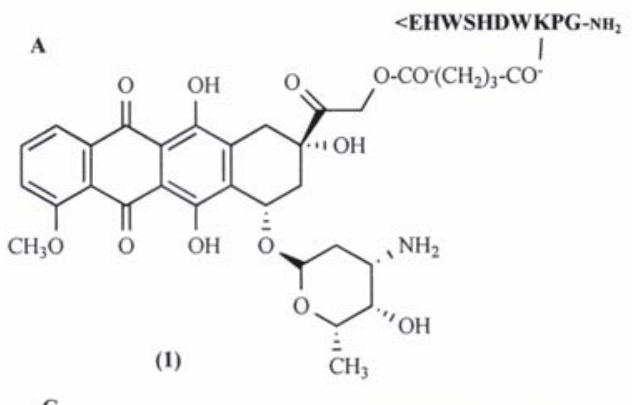

C $<$ EHWSHDWKPG- $\mathrm{NH}_{2}$<smiles>[X]CC(=O)OCC(=O)[C@@]1(O)Cc2c(O)c3c(c(O)c2[C@@H](O[C@H]2C[C@H](N)[C@@H](O)[C@H](C)O2)C1)C(=O)c1c(OC)cccc1C3=O</smiles>

$\mathrm{X}=\mathrm{H}(\mathrm{Dau})(3)$ or $\mathrm{OH}($ Dox $)(4)$

E<smiles>CN(Cc1cnc2nc(N)nc(N)c2n1)c1ccc(C(=O)NC(CCC(=O)NC=CC(=O)[O-])C(N)=O)cc1</smiles>

(9)

Fig. (3). Chemical structure of IGnRH-III-anthracycline derivative conjugates: Dox-IGnRH-III (1) (ester bond) (A); Dau-IGnRH-III (2) (hydrazone bond) (B); Dau-GFLG-IGnRH-III (3) and Dox-GFLG-IGnRH-III (4) (oxime bond) (C); Dau-IGnRH-III (5), Dau-GFLG-IGnRHIII (6), Dox-IGnRH-III (7) Dox-GFLG-IGnRH-III (8) (amide bond) (D) and MTX-GFLGC-IGnRH-III (9) (E). highly water soluble polymer with polyhydroxyl character, was applied as carrier [107]. IGnRH-III was attached to the carrier through amide bond formed between the $\gamma$-carboxyl group of glutamic acid residues in the polymer and the $\varepsilon$ amino group of Lys in IGnRH-III. This conjugation resulted in a moderate increase of antitumor activity compared to the native hormone [108]. Because we had difficulties in synthetic reproduction and characterization of branched chain polymeric polypeptide conjugates, an oligotuftsin derivative with well-defined structure was introduced as carrier [109]. This biodegradable 20-mer peptide, containing a four repeat unit of a pentapeptide (TKPKG), was derived from the canine tuftsin. The side chain of every second Lys residue was modified by a chloroacetyl group either directly or through a GFLG spacer (Ac-[TKPK(ClAc) G $]_{4}-\mathrm{NH}_{2}$ or Ac-[TKPK (ClAc-GFLG)G] $]_{4}-\mathrm{NH}_{2}$ ). The IGnRH-III modified by acetylcysteine on Lys ${ }^{8}$ was conjugated to the carriers via thioether bond formation, resulting in conjugates containing four copies of IGnRH-III [110]. These compounds, however, did not show significant antiproliferative effects on MCF-7 and HT-
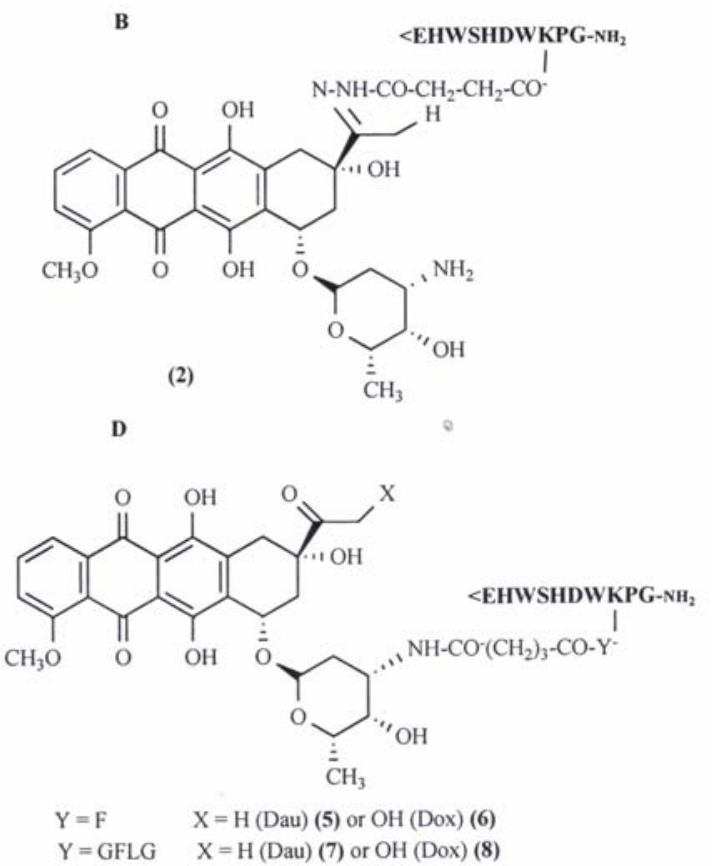

$<$ EHWSHDWKPG-NH

$$
\text { S- }-\mathrm{CH}_{2}-\mathrm{CO}^{-}
$$


29 cell lines. Therefore, further structural modifications of the conjugates are in progress.

\section{GnRH-III-Drug Conjugates for Targeted Chemotherapy}

In our laboratory, IGnRH-III was used for the development of multifunctional drug delivery systems for targeted chemotherapy. IGnRH-III as homing device can deliver the attached drug into tumor cells presenting $\mathrm{GnRH}$ receptors on the cell membrane in a receptor-mediated manner. Daunomycin (Dau), Dox and MTX as anticancer agents were conjugated to IGnRH-III derivatives (Fig. (3)). Mtx was coupled to a GFLGC pentapeptide spacer, followed by the cleavage of the MTX-GFLGC-NH $\mathrm{NH}_{2}$ pentapeptide derivative from the solid support. The $\alpha$ - and $\gamma$-carboxyl-coupled isomers of MTX-GFLGC-NH $\mathrm{N}_{2}$ were separated by HPLC [111]. Finally, the Cys-containing drug-spacer conjugate was attached to chloroacetylated IGnRH-III (<EHWSHDWK(ClAc)PG$\mathrm{NH}_{2}$ ) via thioether bond formation.

It has been mentioned above in this article that the most effective Dox-GnRH conjugate could be prepared by ester bond formation. Dox was first converted to $14-O$-hemiglutarate derivative using glutaric anhydride, and then the free carboxyl group of this conjugate was attached to the $\varepsilon$-amino group of $\left[\right.$ D-Lys $\left.{ }^{6}\right]-$ GnRH $[80,81]$. However, Dau differs from Dox at the $\mathrm{C}-14$ position $(\mathrm{H}$ instead of $\mathrm{OH}$ ) and is not suitable for this type of conjugation $[112,113]$.

The possible conjugation sites of Dau are the oxo group at $\mathrm{C}-13$ for oxime or hydrazone bond formation and the amino group of the sugar moiety [114]. However, modification of the amino group of the sugar moiety might lead to the loss of bioavailability of the compound [115]. Different DauIGnRH-III and Dox-IGnRH-III conjugates were prepared in our laboratory and their long-term in vitro antitumor activity was studied on MCF-7 human breast and C26 murine colon cancer cell lines (Table 3). The most potent compound was the Dox-IGnRH-III conjugate, in wich the drug was attached to the hormone derivative via ester bond. The Dau-IGnRHIII conjugate containing hydrazone bond between the components showed only slightly less activity on MCF-7 cell lines. However, on C26 cell line the oxime bond containing conjugates also demonstrated high activity. On this cell line, the Dau-IGnRH-III conjugate caused significantly higher inhibition of cell proliferation than Dox-IGnRH-III. The differences in activity of the conjugates on different cell types can be explaind by the differences in cellular uptake of the compounds. Preliminary data obtained in our laboratory show that the superagonist triptorelin, even at high doses, was not able to inhibit the cellular uptake of the IGnRH-III conjugates. This observation suggests that receptors other than GnRH-IR and/or GnRH-IIR might play a role in the internalization of IGnRH-III derivatives. Interestingly, the conjugates in which antracycline derivatives were attached to IGnRH-III through the amino-sugar moiety did not show significant antitumor activity even at $100 \mu \mathrm{M}$ concentration. Only the conjugates that contained a GFLG spacer between the hormone and drug had some antiproliferative effect on MCF-7 cell lines but not on colon cancer cell lines. Studies on the mechanisms of receptor binding and internalization of IGnRH-III derivatives are in progress.

The in vivo toxicity and antitumor activity of oxime bond containing Dau-IGnRH-III were also studied in C26 tumor bearing mice. It was found that the treatment of mice with Dau-IGnRH-III conjugate containing more Dau than the lethal dose of free Dau was well tolerated. The conjugate caused similar decrease of tumor growth as the free Dau, but the conjugate-treated animals had longer survival time than the free Dau-treated or control mice [116].

\section{GnRH Dimers}

One natural disulfide dimer derivative of GnRH is the dimer of tunicate GnRH-II, which contains Cys in position 6 $\left(\left[<\text { EHWSLCHAPG- } \mathrm{NH}_{2}\right]_{2}\right)$. Dimerization may lead to increased stability of the compound against degrading enzymes due to spatial inhibition. It can be speculated that each monomeric subunit of the dimer binds to a receptor molecule and thereby enhances microaggregation of receptors, complex formation and internalization $[1,117,118]$. We believe that $\mathrm{GnRH}$ dimers can help crosslinking the $\mathrm{GnRH}$ receptors and thus can amplify the internalization of hormone-receptor complex. For this purpose, IGnRH-III dimer derivatives with disulfide bridge between peptide chains were prepared $[11,110]$. Cysteine was attached to the $\varepsilon$-amino group of lysine in position 8 , either directly or through peptidic and non-peptidic spacers. The amino group of Cys was free or acetylated (e.g. $[<\text { EHWSHDWK(H-C)PG-NH }]_{2},[<$ EHWS $\left.\left.\mathrm{HDWK}(\mathrm{Ac}-\mathrm{C}) \mathrm{PG}-\mathrm{NH}_{2}\right]_{2}\right)$. In antiproliferative assays, the dimers showed higher activity than IGnRH-III on MCF-7 human breast and HT-29 human colon carcinoma cell lines. The presence of acetyl group on the amino group of Cys resulted in an increased activity in vitro. The spacer had also some influence on the antiproliferative effect. One of the

Table 3. Comparision of the In Vitro Antitumor Activity of GnRH-III-Anthracycline Conjugates

\begin{tabular}{|c|c|c|c|c|c|c|c|c|}
\hline Cells Compound & $\begin{array}{c}1 \\
\operatorname{IC}_{s 0}|\mu \mathrm{M}|\end{array}$ & $\begin{array}{c}2 \\
I_{s o}[\mu \mathrm{M}]\end{array}$ & $\begin{array}{c}3 \\
I C_{s 0}[\mu \mathrm{M}]\end{array}$ & $\begin{array}{c}4 \\
I C_{s o}|\mu M|\end{array}$ & $\begin{array}{c}5 \\
I C_{s 0}|\mu M|\end{array}$ & $\begin{array}{c}6 \\
I_{50}[\mu \mathrm{M}]\end{array}$ & $\begin{array}{c}7 \\
I_{50}[\mu \mathrm{M}]\end{array}$ & $\begin{array}{c}8 \\
I C_{s 0}[\mu \mathrm{M}]\end{array}$ \\
\hline MCF-7 & $\begin{array}{c}0.8 \\
\pm 0.5\end{array}$ & $\begin{array}{c}1.5 \\
\pm 0.2\end{array}$ & $\begin{array}{c}3.9 \\
\pm 1.2\end{array}$ & $\begin{array}{c}5.4 \\
\pm 1.9\end{array}$ & $>100$ & $\begin{array}{l}99.7 \\
\pm 4.8\end{array}$ & $>100$ & $\begin{array}{l}84.2 \\
\pm 5.5\end{array}$ \\
\hline $\mathrm{C} 26$ & $\begin{array}{c}4.8 \\
\pm 0.1\end{array}$ & $\mathrm{nt} \mathrm{t}^{\circ}$ & $\begin{array}{l}22.5 \\
\pm 1.7\end{array}$ & $\begin{array}{l}46.1 \\
\pm 6.1\end{array}$ & $>100$ & $>100$ & $>100$ & $>100$ \\
\hline
\end{tabular}

Dox-IGnRH-III (1) (ester bond) (A); Dau-IGnRH-III (2) (hydrazone bond) (B); Dau-GFLG-IGnRH-III (3) and Dox-GFL G-IGnRH-III (4) (oxime bond) (C); Dau-IGnRH-III (5), Dau-GFLG-IGnRH-III (6), Dox-IGnRH-III (7) Dox-GFLG-IGnRH-III (8) (amide bond) (D) IC $_{50}$ values were calculated by MTT assay; the free drugs had IC so $_{0}$ values of $0.1-0.2 \mu \mathrm{M}$ (MCF-7) and 2-5 $\mu \mathrm{M}$ (C26). nt $=$ not tested. 
most potent dimer analogs inhibited proliferation of $\mathrm{MCF}-7$ and HT-29 carcinoma cells by $50-60 \%$, while the monomer caused only $15-20 \%$ inhibition in this experiment.

Preliminary in vivo experiments indicated that intraperitoneal (i.p.) treatment of nude mice bearing HT-29 colon tumor xenograft with IGnRH-III dimers resulted in significant inhibition of tumor growth. Ten days following the treatment, a $44 \%$ inhibition of tumor growth could be still observed in the dimer-treated groups. With regard to novelty, these results were the first to demonstrate that $\mathrm{GnRH}$ analogs containing only $\mathrm{L}$-amino acids have significant antitumor effect on GnRH-R-positive human colon carcinoma in vivo. The LH-stimulatory effect of the IGnRH-III dimer derivatives on rat pituitary cells was lower than that of the IGnRHIII monomer [11]. This is in agreement with the finding that the elimination of basic character at position 8 decreases the endocrine activity of IGnRH-III derivatives and indicates that dimerization significantly increases the antitumor selectivity of IGnRH-III. The application of GnRH dimer analogs with selective anticancer activity provides a new prospect for the complex therapy of GnRH-R-positive cancers.

\section{Enzymatic Stability}

Development of new potent GnRH analogs is of major interest, especially due to their clinical applications in modulating the reproductive system as well as in cancer therapy. The oral route is considered to be very convenient for the delivery of drugs. However, oral delivery is challenging due to the presence of biochemical and physical barriers in the gastro-intestinal tract such as (i) the acidic pH; (ii) the pancreatic endopeptidases chymotrypsin, trypsin and elastase and (iii) the endo- and exopeptidases associated with the intestinal brush-border (angiotensin converting enzyme ACE, aminopeptidases and carboxypeptidases) [119,120]. On the other hand, due to the presence of an N-terminal pyroglutamate residue and a C-terminal glycine amide, $\mathrm{GnRH}$ analogs are not expected to be hydrolyzed by exopeptidases in the intestinal lumen.

Using capillary electrophoresis, Walker et al. and Ledger et al. analyzed the proteolytic stability of human and salmon GnRH against pancreatic endopeptidases and found that both $\mathrm{GnRH}$ analogs can be rapidly hydrolyzed by $\alpha$ chymotrypsin, whereas in the presence of elastase they are only slowly hydrolyzed. Trypsin had no activity on GnRH analogs, even after incubation for $2 \mathrm{~h}$. Degradation of $\mathrm{GnRH}$ analogs by elastase is likely to be a property of the chymotrypsin impurity and therefore protection of the analogs from $\alpha$-chymotrypsin is a requirement for the development of orally absorbable products $[121,122]$. Similar observations were made in our laboratory with IGnRH-III. Monomeric IGnRH-III and its dimer derivative [IGnRH-III(Ac-Cys) $]_{2}$ were subjected to trypsin and $\alpha$-chymotrypsin proteolysis at an enzyme to substrate ration of 1:50 [11]. According to the HPLC and mass spectrometric analyses of the reaction mixtures, both compounds were stable in the presence of trypsin for at least $24 \mathrm{~h}$. In the case of $\alpha$-chymotrypsin catalyzed hydrolysis of monomeric IGnRH-III, the decapeptide was completely digested after $1 \mathrm{~h}$. The main cleavage sites were the amide bond between $\operatorname{Trp}^{3}$ and $\mathrm{Ser}^{4}$, followed by the cleavage of $\operatorname{Trp}^{7}-$ Lys $^{8}$ peptide bond. The dimer [IGnRH-
III(Ac-Cys) $]_{2}$ contains four potential $\alpha$-chymotrypsin cleavage sites. Similarly to the monomeric IGnRH-III, the main cleavage occurred between $\operatorname{Trp}^{3}$ and $\mathrm{Ser}^{4}$ amino acid residues, with some differences in the rate of degradation between the two "arms" of the dimer. HPLC chromatograms recorded after 3 and $6 \mathrm{~h}$ showed the presence of only two peaks corresponding to the ${ }^{1} \mathrm{GlpHW}{ }^{3}$ and $\left[\mathrm{H}^{-4} \mathrm{SHDWK}\right.$ (AcC) $\left.\mathrm{PG}^{10}-\mathrm{NH}_{2}\right]_{2}$ fragments. No significant degradation was observed at the second cleavage site $\operatorname{Trp}^{7}$-Lys ${ }^{8}$ even after 24 h.

We also investigated the $\alpha$-chymotryptic digestion of a Dau-IGnRH-III conjugate, in which daunomycin was attached to IGnRH-III(GFLG) through an oxime bond [116]. Similarly to $[\mathrm{GnRH}-\mathrm{III}(\mathrm{Ac}-\mathrm{Cys})]_{2}$, the peptide bond $\operatorname{Trp}^{3}$ $\mathrm{Ser}^{4}$ in the conjugate was the most susceptible to $\alpha$ chymotrypsin catalyzed hydrolysis. Two more cleavage sites were identified after longer incubation times, Leu-Gly and Phe-Leu in the GFLG branch. No digestion of $\operatorname{Trp}^{7}-\mathrm{Lys}^{8}$ was observed.

The work by Zheng et al. indicated that leuprolide acetate (5-Oxo-Pro-His-Trp-Ser-Tyr-D-Leu-Leu-Arg-ProNHEt acetate), a potent GnRH receptor agonist, was rapidly degraded by chymotrypsin and by rat intestinal mucosa homogenates. It was shown that both the absorption and enzymatic degradation of leuprolide in the gastro-intestinal tract is site-dependent, and the lower intestine may be an advantageous region for absorption of leuprolide [123]. In order to stabilize leuprolide against chymotrypsin and intestinal degradation, several GnRH agonists modified at position 1, 2, or 3 and/or containing $N$ - $\alpha$-methyl at positions 1,2 , or 4 were prepared. Complete stabilization against chymotrypsin and lumenal degradation was achieved with substitution of NMe$\mathrm{Ser}^{4}$ in leuprolide, however, with an increase in clearance [124].

The degradation of $\mathrm{GnRH}$ was also determined in various pig tissues, such as buccal, liver, nasal, and skin tissues and their corresponding homogenates [125]. Degradation rates of GnRH in intact tissues were lower than in their corresponding homogenates. The intact skin tissue demonstrated the lowest and liver the highest degradation rate among the four intact tissues. Based on the minimal proteolytic activity of the skin, transdermal delivery was suggested as a suitable route for administering GnRH analogs. The effect of constant and pulsed iontophoresis on the delivery and stability of GnRH and Nafarelin in human skin was compared [126]. In this study, five major hydrolytic degradation products of $\mathrm{GnRH}$ were identified. The major epidermal break-up place was between amino acids 5 (tyrosine) and 6 (glycine), whereas no degradation products of Nafarelin could be detected. Results of this study show that the use of pulsed direct current may offer significant benefit in the iontophoretic peptide delivery.

The lung has increasingly being investigated as a possible route for systemic delivery of drugs. The enzymatic degradation of $\mathrm{GnRH}$ and [D-Ala $\left.{ }^{6}\right]-\mathrm{GnRH}$ in various alveolar pneumocytes was evaluated $[127,128]$. Pulmonary macrophages exhibited the strongest proteolytic activity against the peptides, followed by type II and type I -like pneumocytes. Three major degradation products of $\mathrm{GnRH}$, such as GnRH(4-10), GnRH(6-10) and GnRH(7-10) were identified. 
In all cell types, the degradation rate of [D-Ala $\left.{ }^{6}\right]-G n R H$ was about 3-8 times lower than that of GnRH. This GnRH analog was resistant to degradation by EP24.15 (Tyr -Gly $^{6}$ cleavage site) and EP24.11 (Gly ${ }^{6}$-Leu ${ }^{7}$ cleavage site) but was susceptible to ACE ( $\operatorname{Trp}^{3}-\mathrm{Ser}^{4}$ cleavage site) mediated cleavage.

Disposition and metabolism of Cetrorelix, a potent GnRH receptor antagonist, was studied after s.c. injection to intact and bile duct cannulated rats and dogs $[129,130]$. In urine of both species, only intact Cetrorelix could be detected. However, in bile and feces of the dogs and rats qualitatively the same metabolites, characterized as truncated peptides of the parent decapeptide, were found. The major metabolite in bile was the (1-7) heptapeptide (Ac-D-Nal(2)D-Phe( $p$ Cl)-D-Pal(3)-Ser-Tyr-D-Cit-Leu-OH). The amount of the (1-4) tetrapeptide (Ac-D-Nal(2)-D-Phe( $p$ Cl)-D-Pal(3)Ser-OH) in the feces of rats but not in that of dogs increased with time, suggesting additional degradation of the peptide in the gastrointestinal tract of rats by enteric metabolization.

Considering that kidney has been identified as the organ with special relevance concerning the pharmacokinetic fate of $\mathrm{GnRH}$ analogs, high-performance liquid chromatography combined with electrospray mass spectrometry was applied to identify the degradation products resulting from the incubation of two GnRH analogs, [D-Phe $\left.{ }^{6}\right]-G n R H$ and D$\mathrm{Ser}(\mathrm{OtBu})^{6}$-desGly ${ }^{10}$-GnRH-ethylamide (buserelin) with rat kidney membranes [131]. Despite their structural differences at the C-terminus, both analogs were degraded in the same way, the main cleavage sites being around the serine residue: $\mathrm{Trp}^{3}-\mathrm{Ser}^{4}$ and $\mathrm{Ser}^{4}-\mathrm{Tyr}^{5}$.

Taking into account all these data, one can conclude that minor modifications of $\mathrm{GnRH}$ analogs can lead to compounds with increased enzymatic stability and antitumor effect. Both IGnRH-III dimer derivative and Dau-IGnRH-III conjugate have increased stability in the presence of chymotrypsin compared to the monomeric IGnRH-III. These results provide a basis for further development of potential anticancer agents that are exclusively composed of L-amino acids and/or of homing devices for targeted chemotherapy with increased enzymatic stability.

\section{CONCLUSION}

Targeted chemotherapy might provide a breakthrough in the cancer treatment in the 21 st century. Several strategies were developed in order to increase the selectivity of drugs by targeting them directly to tumor cells. One of the most promising procedures is the application of hormonal peptides that bind directly to their receptors that are overexpressed on tumor cells. Derivatives of IGnRH-III are good candidates for this purpose due to their low endocrine effect and high antiproliferative activity. It was demonstrated that IGnRH-III can be used as targeting moiety for drug delivery. Based on the findings that conjugation or dimerization of IGnRH-III and its derivatives increase their selective antitumor activity, GnRH dimers and conjugates are currently used for the development of drug delivery systems.

\section{ACKNOWLEDGEMENTS}

This work was supported by grants OTKA-46098, 42884, -49814, ETT202/2006, by MediChem-2 1/A/005/ 2004 and by GVOP-3.2.1.-2004-04-0005/3.0.

\section{ABBREVIATIONS}

\begin{tabular}{|c|c|c|}
\hline Ac & $=$ & Acetyl \\
\hline $\mathrm{AC}$ & $=$ & Adenyl cyclase \\
\hline $\mathrm{ACE}$ & $=$ & Angiotensin converting enzyme \\
\hline $\mathrm{A}_{2} \mathrm{bu}$ & $=$ & 2,4-diaminobutiric acid \\
\hline $\mathrm{A}_{2} \mathrm{pr}$ & $=$ & 2,3-diaminopropionic acid \\
\hline AP-1 & $=$ & Activator protein-1 \\
\hline CE & $=$ & Carboxylesterase enzymes \\
\hline $\mathrm{CPC}$ & $=$ & Cyclopropanecarbonyl \\
\hline CPT & $=$ & Camptothecin \\
\hline BH3 & $=$ & BCL-2 homology domain 3 \\
\hline Boc & $=$ & Tert-butyloxycarbonyl \\
\hline BOP & $=$ & $\begin{array}{l}\text { Benzotriazol-1- } \\
\text { yloxytris(dimethylamino)phosphonium hex- } \\
\text { afluorophosphate }\end{array}$ \\
\hline BRCA & $=$ & Breast cancer antigen \\
\hline DDS & $=$ & Drug delivery system \\
\hline DIC & $=$ & $N, N^{\prime}$-diisopropylcarbodiimide \\
\hline D-Mel & $=$ & $\begin{array}{l}\text { D-melphalan } \\
\text { phenylalanine) }\end{array}$ \\
\hline Dox & $=$ & Doxorubicin \\
\hline E2 & $=$ & Estradiol \\
\hline EA & $=$ & Ethylamide \\
\hline EGF & $=$ & Epidermal growth factor \\
\hline EGFR & $=$ & Epidermal growth factor receptor \\
\hline ER & $=$ & Estrogen receptor \\
\hline ERK $1 / 2$ & $=$ & Extracellular signal-regulated kinase 1 and 2 \\
\hline Et & $=$ & Ethyl \\
\hline FSH & $=$ & Follicle stimulating hormone \\
\hline Gi & $=$ & G-protein $\alpha \mathrm{i}$ \\
\hline Glp $(<$ E) & $=$ & Pyroglutamic acid \\
\hline GnRH & $=$ & Gonadotropin-releasing hormone \\
\hline GnRH-R & $=$ & Gonadotropin-releasing hormone receptor \\
\hline GPCR & $=$ & G-protein-coupled receptor \\
\hline HA & $=$ & Hyaluronan \\
\hline HMAQG & $=$ & $\begin{array}{l}\text { (2-hydroxymethyl)anthraquinone } \\
\text { hemiglutarate }\end{array}$ \\
\hline HPLC & $=$ & High performance liquid chromatography \\
\hline $\mathrm{IC}_{50}$ & $=$ & $50 \%$ inhibition concentration \\
\hline IGF-1 & $=$ & Insulin-like growth factor-1 \\
\hline IGF-1R & $=$ & Insulin-like growth factor-1 receptor \\
\hline i.p. & $=$ & Intraperitoneal \\
\hline JNK & $=$ & c-Jun $\mathrm{N}$-terminal kinase \\
\hline LH & $=$ & Luteinising hormone \\
\hline
\end{tabular}




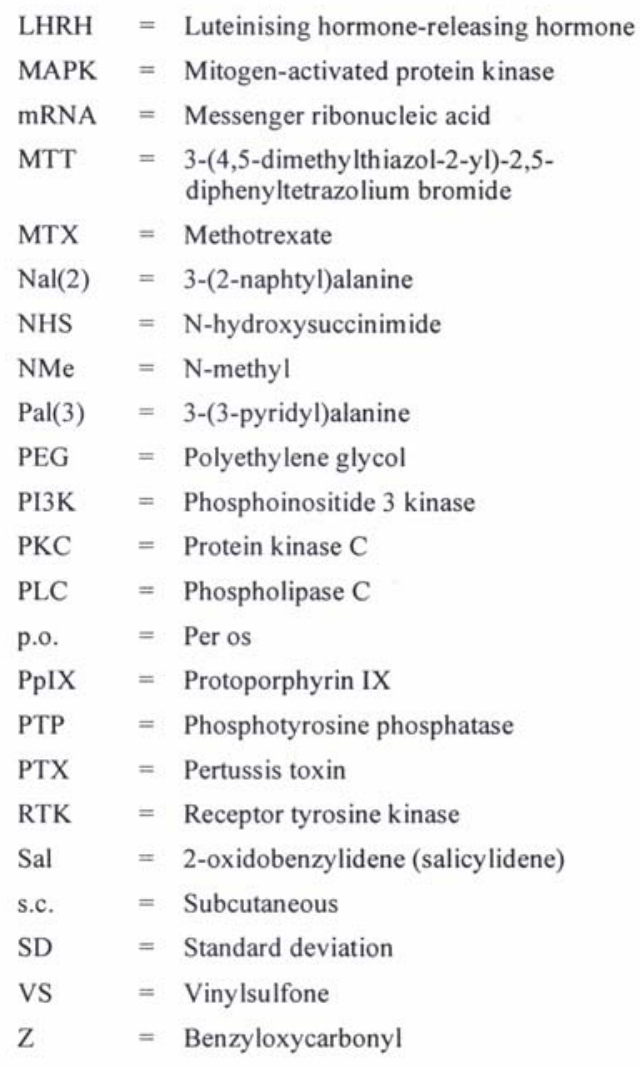

\section{REFERENCES}

[1] Schally, A. V.; Nagy, A. Trends Endocrinol. Metab., 2004, 15, 300. [2] Reuibi, J.C. Endocr. Rev., 2003, 24, 389

[3] Schally, A. V.; Nagy, A. Life Sci. 2003, 72, 2305,

[4] Millar, R.P.; Lu, Z.L.; Pawson, A.J.; Flanagan, C.A.; Morgan, K. Maudsley, S.R. Endocr. Rev, 2004, 25, 235.

[5] Ben-Yehudah, A.; Lorberboum-Galski, H. Expert Rev. Anticancer Ther., 2004, 4, 151 .

[6] Pályi, I.; Vincze, B.; Lovas, S.; Mezō, I.; Pató, J., Kálnai, A.; Túri, G.; Gaál. D.; Mihalik, R.; Péter, I.; Teplán, I.; Murphy, R.F. Proc. Natl. Acad. Sci. USA, 1999, 96, 2361

[7] Pályi, I.; Vincze, B.; Kálnay, A.; Tủri, G.; Mezō, I.; Teplán, L. Seprödi, J.; Pató, J.; Móra, M. Canc. Detect. Prevent., 1996, 20, 146.

[8] Mezō, L; Lovas, S; Pályi, L; Vincze, B; Kálnay, A; Túri, G. Vadász, Z.; Seprōdi, J.; Idei, M.; Tóth, G.; Gulyás, E.; Otvős, F. Mák, M.; Horváth, J.E.; Teplán, I.; Murphy, R.F. J. Med. Chem. Mák, M.; Horvầ,

[9] Millar, R.P. Trends Endocrinol. Metab., 2003, 14, 35

[10] Lovas, S.; Pályi, I.; Vincze, B.; Horváth, J.; Kovács, M.; Mezô, L. Tóth, G.; Teplán, I.; M urphy, R.F. J. Pept. Res., 1998, 52, 384

[11] Mezö, G.; Czajlik, A.; Manea, M.; Jakab, A; Farkas, V.; Majer, Zs.; Vass, E.; Bodor, A.; Kapuvári, B.; Boldizsár, M. Vincze, B. Csuka, O.; Kovács, M.: Przybylski, M.: Perczel, A.; Hudecz, F. Peptides, 2007, 28, 806.

[12] Kovács, M.; Vincze, B.; Horváth, J.E;; Seprōdi, J. Peptides, 2007, 28,821

[13] Schally, A.V.; Arimura, A.; Kastin, A.J.; Matsuo, H.; Baba, Y.; Redding, T.W.; Nair, R.M.; Debeljuk, L.; White, W.F. Science, $1973,173,1036$.
[14] Millar, R.P. Anim. Reprod. Sci., 2005, 88, 5

[15] Neill, J.D.; Musgrove, L.C.; Duck, L.W. Trends Endocrinol. Metab., 2004, 15, 383.

[16] White, R.B.; Eisen, J.A.; Kasten T.L.; Fernald R.D. Proc. Natl. Acad. Sci. USA, 1998, 95, 305.

[17] Conn, P.M.: Huckle, W.R: Anders, W.V: McArdle, C.A. Rec, Prog. Horm. Res., 1987, 43, 29.

[18] Schally, A.V.; Comaru-Schally, A.M.; Nagy, A: Kovács, M.; Szepesházi, K.; Plonowski, A.; Varga, J.L.; Halmos, G: Front. Neuroendocrinol., 2001, 22, 248

[19] Schally, A.V.; Comaru-Schally A.M. In Cancer Medicine, Holland, J.F.; Frei, E.; Bast, R.C.; Kufe, D.E; Pollock, R.E. \& Weichselbaum, R.R. Eds.; Dekker New York, 5th Ed., 2000, pp. 715-29.

[20] Reissmann, T; Schally, A. V; Bouchard, P. Riethmuller, H.; Engel, J. Hum. Reprod. Update, 2000, 6,322.

[21] Neill, J.D. Endocrinology, 2002, 143, 737.

[22] Kovács, M.; Koppán, M.; Mezô, 1.; Teplản, I.; Flerkó, B. J. Neuroendocrinol., 1993, 5, 603.

[23] Kovács, M.; Schally, A.V. Proc. Natl. Acad. Sci. USA, 2001, 98, 12197.

[24] Ji, T.H.; Grossmann M.; Ji, I. J. Biol. Chem., 1998, 273, 17299.

[25] Wess, J. FASEB J., 1997, II, 346. [26] Shedgley, K.R.; Finch, A.R; Caunt, C.J.; McArdle, C.A. J.

[27] Gründker, C.; Schlotawa, L.; Viereck, V.; Eicke, N.; Horst, A.; Kairies, B.; Emons, G. Eur. J. Endocrinol., 2004, 151, 414

[28] Völker, P.; Gründker, C.; Schmidt, O.; Schultz, K-D.; Emons, G. Am. J. Obstet. Gynecol., 2002, 186, 171.

[29] Kakar, S.S.; Grizzle, W.E.; Neill, J.D. Mol. Cell. Endocrinol., 1994, 106, 145 .

[30] Gründker, C.; Günthert, A.R.; Westphalen, S.; Emons, G. Eur. J. Endocrinol., 2002, 146,1.

[31] Miller, W.R.; Scott, W.N.; Morris, R.; Fraser, H.M.; Sharpe, R.M.; Nature, $1985,3 / 3,231$

[32] Eidne K.A.; Flanagan, C.A., Millar, R. P. Science, 1985, 229, 989

[33] Fekete, M.; Wittliff J.L.; Schally, A.V. J. Clin. Lab. Anal., 1989, 3 , 137.

[34] Baumann, K.H.; Kiesel, L.; Kaufmann, M.; Bastert, G.; Runnebaum, B. Breast Cancer Res. Treat., 1993, 25, 37.

[35] Quajum, A.; Gullick, W., Clayton, R.C.; Sikora, K.; Waxman, J. Br. J. Cancer, 1990, 62, 96

[36] Limonta, P.; Dondi, D.; Roberta, Ma Moretti, R.M.; Fermo, D; Garattini, E.; Motta, M. J. Clin. Endocrinol. Metab., 1993; 76, 797.

37] Straub, B.: Muller, M.: Krause, H.; Schrader, M.; Goessl, C.; Heicapell, R.; Miller, K. Clin. Cancer Res., 2001, 7, 2340.

[38] Nagy, A.; Schally, A. V. Biol. Reprod., 2005, 73, 851.

[39] Mangia, A. Tommasi, S. Reshkin, S.J. Simone, G.; Stea, B.; Schittulli, F.; Paradiso, A. Oncol Rep., 2002, 6, 1127.

[40] Kottler, M.R.; Starzec, A.; Carre, M.C.; Lagarde, J.P.; Martin, A.; Counis, R., Int. J. Cancer, 1997, 71, 595

[41] Limonta, P.; Moretti, R. M.; Marelli, M. M.; Dondi, D.; Parenti, M.; Motta, M. Endocrinology, 1999, 140, 5250.

[42] Krsmanovic, L.Z; Mores, N.; Navarro, C.E.; Arora, K.K.; Catt, K.J. Proc. Natl. Acad. Sci. USA, 2003, 100, 2969

[43] Tieva, A.; Stattin, P.; Wikström, P.; Bergh, A.; Damber, J.-E. Prostate, 2001, 47, 276.

[44] Gründker, C.; Vǒlker, P.; Griesinger, F.; Ramaswamy, A.; Nagy, A.; Schally, A.V.; Emons, G. Am. J. Obstet. Gynecol., 2002, 187, 528 .

[45] Fister, S.; Günthert, A.R.; Emons, G.; Gründker, C. Cancer Res. $2007,67,1750$

[46] Leung, P.C.K.; Choi, J.-H. Hum. Reprod. Update, 2007, 13, 143.

[47] Pawson, A.J: Morgan, K: Stuart, R: Maudsley, R: Millar, R.P. Reproduction, 2003, 126,271.

[48] Millar, R.P.; Pawson, A.J.; Morgan, K.; Rissman, E.F; Lu, Z-L. Front. Neuroendocr., 2008, 29, 17.

[49] Pfleger, K.D.G.; Pawson, A.J.; Millar, R.P. Endocrinology, 2008, 149, 3118 .

[50] Gründker, C.; Vōlker, P.; Günthert, A. R.; Emons, G. Endocrinology, 2001, 142, 2369 .

[51] Gründker, C;: Völker, P.; Schulz, K.D;: Emons, G. Gynecol. Oncol., 2000, 78, 194

[52] Harrison, G.S.; Wierman, M.E.; Nett, T.M.; Glode, L.M. EndocrRelat. Cancer, 2004, 11, 725 . 
[53] Chen, A.; Kagonovsky, E.; Rahimipour, S.; Ben-Aroya, N.; Okon, E.; Koch, Y. Cancer Res., 2002, 62, 1036.

[54] Nickerson, T; Chang, F; Lorimer, D.; Smeekens, S. P; Sawyers, C.: Pollak, M. Cancer Res., 2001, 61, 6276.

[55] Marelli, M.M.; Moretti, R.M.; Mai, S.; Procacci, P.; Limonta, P. Int. J. Oncol., 2007, 30, 261.

[56] Enomoto, M.; Utsumi, M.; Park, M.K. Endocrinology, 2006, 147, 530

[57] Gründker, C.; Emons, G. Reprod. Biol. Endocrinol., 2003, I, 65.

[58] Wang, L.; Bogerd, J.; Choi, H.S.; Seong, J.Y.; Soh, J.M.; Chun, S Y.; Blomenrohr, M.; Troskie, B.E.; Millar, R.P.; Yu, W.H.; McCann, S.M.; Kwon, H.B. Proc. Natl. Acad. Sci. USA, 2001, 98, 361 .

[59] Millar, R.; Lowe, S.; Conklin, D.; Pawson, A.; Maudsley, S.; Troskie, B.; Ott, T.; Millar, M.; Lincoln, G.; Sellar, R.; Faurholm, B.; Scobie, G.; Kuestner, R.; Terasewa, E.; Katz, A. Proc. Natl. Acad. Sci. USA, 2001, 98, 9636.

[60] Neill, J.D.; Duck, W.; Sellers, J.C.; Musgrove, L.C. Biochem. Biophys. Res. Commun., 2001, 282, 1012.

[61] Caunt, C.J.; Finch, A.R.; Sedgley, K.R.; Oakely, L.; Luttrell, L.M. McArdle, C.A. J. Biol. Chem., 2006, 281, 2701

[62] Cheng, C.K.; Leung, P.C.K. Endocr. Rev., 2005, 26, 283.

[63] Eicke, N.; Günthert A.R.; Viereck, V.; Siebold, D.; Béhé, M. Becker, T.; Emons, G.; Grünther, C. Eur. J. Endocrinol., 2005 153,605 .

[64] Günthert, A.R: Gründker, C.; Olota, A.; Läsche, J.; Eicke, N. Emons, G. Eur. J. Endocrinol., 2005, 153,613.

[65] Morgan, K.; Conklin, D.; Pawson, A.J.; Sellar, R.; Ott, T.R. Millar, R.P. Endocrinology, 2003, 144,423 .

[66] Gründker, C.; Günthert, A.R.; Millar, R.P.; Emons, G. J. Clin. Endocr. Metab., 2002, 87, 1427

[67] Dondi, D.: Limonta, P.; Moretti, R.M.; Marelli, M.M.; Garattini, E.: Motta, M. Cancer Res., 1994, 8, 4091

[68] Koppán, M.; Nagy, A.; Schally, A.V.; Plonowski, A.; Halmos, G. Arencibia, J.M.; Groot, K. Prostate, 1999, 38, 151 .

[69] Kim, K.Y.; Choi, K.C.; Park, S.H.; Chou, C.S.; Auersperg, N.; Leung, P.C. J. Clin. Endocr. Metab., 2004, 89, 3020

[70] Eicke, N.; Günthert, A.R.; Emons, G.; Gründker, C. Int. J. Oncol. 2006, 29, 1223

[71] Von Alten, J.; Fister, S.; Schulz, H.; Viereck, V.; Frosch, K.H Emons, G.; Gründker, C. Breast Cancer Res. Treat., 2006, 100, 13.

[72] Kim, K.Y.; Choi, K.C.; Auersperg, N.; Leung, P.C.K. Endocr. Relat. Cancer, 2006, 13,211

[73] Isaacs, J.T.; Coffey, D.S. Cancer Res., 1984, 4I, 5070.

[74] Isaacs, J.T. Prostate 1984, 5, 1.

[75] Bajusz, S.; Janáky, T.; Csernus, V.J.; Bokser, L.; Fekete, M. Skralovic, G.; Redding, T. W.; Schally, A.V. Proc. Natl. Acad. Sci Skralovic, G.; Redding,

[76] Bajusz, S.; Janáky, T.; Csernus, V.J.; Bokser, L.; Fekete, M. Skralovic, G.; Redding, T.W.; Schally, A.V. Proc. Natl. Acad. Sci. USA, 1989, 86, 6313.

[77] Janáky, T.; Juhász, A.; Bajusz, S.; Csernus, V.J.; Skralovic, G. Bokser, L.; Milovanovic, S.; Redding, T.W.; Rékasi, Z; Nagy, A. Schally, A.V. Proc. Natl. Acad. Sci. USA, 1992, 89, 972 .

[78] Nagy, A.; Szöke, B.; Schally, A.V. Proc. Natl. Acad. Sci. USA. $1993,90,6373$

[79] Janáky, T; Juhász, A.; Rékasi, Z; Serfōzō, P; Pinski, J.; Bokser, L.; Skralovic, G.; Milovanovic, S.; Redding, T.W.; Halmos, G. Nagy, A.; Schally, A.V. Proc. Natl. Acad. Sci. USA, 1992, 89 10203

[80] Nagy A.; Armatis, P.; Schally, A.V. Proc. Natl. Acad. Sci. USA, $1996,93,2464$

[81] Nagy A.; Schally, A.V.; Armatis, P.; Szepesházi, K.; Halmos, G.; Kovács, M.; Zarándi, M.; Groot, K.; Miyazaka, M.; Jungwirth, A.; Horváth, J. Proc. Natl. Acad. Sci. USA, 1996, 93, 7269

[82] Keller, G.; Schally, A. V.; Gaiser, T.; Nagy A.; Baker, B.; Halmos, G.; Engel, J.B. Eur. J. Cancer, 2005, 4I, 2196.

[83] Keller, G.; Schally, A.V.; Gaiser, T.; Nagy A.; Baker, B. Westphal, G.; Halmos, G.; Engel, J.B. Cancer Res., 2005, 65, 5857

[84] Kaliste-Korhonen, E.; Tuovinen, K.; Hănninen, O. Hum. Exp. Toxicol., 1996, 15, 972 .

[85] Nagy, A.; Plonowski, A.; Schally, A.V. Proc. Natl. Acad. Sci. USA. $2000,97,829$.
[86] Rahimipour, S: Ben-Aroya, N.: Ziv, K: Chen, A.; Fridkin, M: Koch, Y. J. Med. Chem., 2003, 46, 3965 .

[87] Anderson, L.; Milligan, G.; Eidne, K.A. J. Endocrinology, 1993. 136,51

[88] Reed, J. J.Clin. Oncol., 1999, 17, 2941.

[89] Lowe, S. W.: Liu, A.W. Carcinogenesis, 2000, 2l, 485

[90] Lowe, S.W: Cosulich, S.C. Worrall, V.; Hedge, P.J.; Green, S.; Lowe, S.W., Cosulich,

[91] Dharap, S.S.; Minko, T. Pharm. Res., 2003, 20,889.

[92] Minko, T.; Dharap, S.S.; Pakunlu, B.I.; Colaizzi, J.L. Dis. Manage Clin. Outcomes, 2001, 3,48.

[93] Dharap, S.S.; Qui, B.; Williams, G.C.; Sinko, P.; Stein, S.; Minko, T. J. Control. Release, 2003, 9I, 61.

[94] Dharap, S.S., Wang, Y.; Chandna, P.; Khandare, J.J.; Qui, B. Gunaseelan, S.; Sinko, P.J.; Stein, S.; Farmanfarmaian, A.; Minko, T. Proc. Natl. Acad. Sci. USA, 2005, 102, 12962.

[95] Khandare, J.J.; Chandna, P.; Wang, Y.; Pozharov, V.P.; Minko, T J. Pharm. Exp. Ther., 2006, 317, 929 .

[96] Chandna, P. Saad, M. Wang, Y: Ber, E.; Khandare, J: Vetcher, A.A.; Soldatenkov, V.A.; Minko, T. Mol. Pharm., 2007, 4, 668

[97] Sower, S.A.; Chiang, Y.C.; Lovas, S.; Conlon, J.M. Endocrinology. 1993, 132, 1125 .

[98] Kálnay, A.; Pályi, I.; Vincze, B.; Mihalik, R.; Mezō, I.; Pató, J.; Seprōdi, J.; Lovas, S.; Murphy, R.F. Cell Prolif., 2000, 33, 275.

[99] Herédi-Szabó, K.; Lubke, J.; Tóth, G.; Murphy, R.F.; Lovas, S. Peptides, 2005, 26, 419

[100] Herédi-Szabó, K.; Murphy, R.F.; Lovas, S. J. Pept. Sct., 2006, 12, 714.

[101] Pinski, J.; Schally, A.V.; Yano, T.; Groot, K.; Srkalovic, G.; Serfözō, P.; Reissmann, T.; Bernd, M.; Deger, W.; Kutscher, B.; Engel, J. Int. J. Pept. Protein Res., 1995, 45, 410.

[102] Mezö, G.; Szabó, I:; Bösze, Sz.; Szabó, R.; Jakab, A.; Bai, K.B: Kapuvári, B.; Vineze, B.; Boldizsár, M.; Csuka, O.; Kovács, M.; Hudecz, F. Peptides 2006. Kenes International, Geneva, Hudecz, F. Peptides 2006. Kenes International, Geneva,

[103] Maeda, H.; Ueda, M.; Morinaga, T.; Matsumoto, T. J. Med. Chem., $1985,28,455$

[104] Azori, M. CRC Crit. Rev. Drug. 1987, 4, 39

[105] Omelyanenko, V: Kopeckovả, P.; Gentry, C.; Kopecek, J. J. Control. Release, 1998, 53, 25.

[106] Pató, J.; Móra, M.; Mezö, I.; Seprơdi, J.; Teplán, I.; Vincze, B.; Kálnay, A.; Pályi, I. J. Bioact. Compat. Polymers, 1999, 14, 304

[107] Mezó, G.; Reményi, J.; Kajtár, J.; Barna, K.; Gaál, D.; Hudecz, F. J. Control. Release, 2000, 63, 81 .

[108] Mezō, G.; Mezō, I.; Vincze, B.; Kálnay, A.; Hudecz, F. Cancer Detect. Prev., 1998, 22S, 239

[109] Mezö, G.; Kalászi, A.; Reményi, J; Majer, Zs.; Hilbert, Á.; Láng, O.; Köhidai, L.; Barna, K.; Gaál, D.; Hudecz, F. Biopolymers. 2004, 73, 645

[110] Mezö, G.; Manea, M.; Jakab, A.; Kapuváry, B.; Bősze, Sz.,; Schlosser, G.; Przybylski, M.; Hudecz, F. J. Pept. Sci., 2004, 10, 701

[111] Mezô, G.; Láng, O.; Jakab, A.; Bai, K.B.; Szabó, I.; Schlosser, G.; Láng, J.; Köhidai, L.; Hudecz, F. J. Pept. Sct., 2006, 12, 328.

[112] Gilladoga, A. C.; Manuel, C.; Tan, C. T.; Wollner, N.; Sternberg, S. S.; Murphy, M. L. Cancer, 1976, 37, 1070.

[113] Minotti, G.; Cavaliere, A. F.; Mordente, A.; Rossi, M.; Schiavello, R.; Zamparelli, M.; Possati, G.-F. J. Clin. Invest., 1995, 95, 1595.

[114] Shao, J.; Tam, J.P. J. Am. Chem. Soc., 1995, 117, 3893.

[115] Gao, Y-G.; Liaw, Y-C.; Li, Y-K.; van der Marel, G. A.; van Boom, J. H.; Wang, A. H-J. Proc. Natl. Acad. Sci. USA, 1991, 88,4845

[116] Szabó, 1.; Manea, M.; Bősze, S.z.; Szabó, R.; Orbán, E.; Gaál, D.; Przybylski, M.; Hudecz, F.; Mezō, G. J. Med. Chem., 2008 (submitted).

[117] Gregory, H.; Taylor, C.L.; Hopkins, C.R. Nature (London), 1982, 300,269 .

[118] Powell, J.F. Reska-Skinner, S.M. Prakash, M.O. Fischer, W.H.: Park, M.; Rivier, J.E.; Craig, A.G.; Mackie, G.O.; Sherwood, N.M. Proc. Natl. Acad. Sci. USA, 1996, 93, 10461

[119] Woodley, J.F. Crit. Rev. Ther. Drug Car. Syst., 1994, II, 61

[120] Langguth, P.; Bohner, V.; Heizmann, J.; Merkle, H.P.; Wolffram, S. Amidon, G.L.: Yamashita, S. J. Control. Release, 1997, 46, 39.

[121] Walker, G.F.; Ledger, R.; Tucker, I.G. Int. J. Pharm., 2001, 216, 77 
[122] Ledger, R: Tucker, IG.; Walker, G.F. J. Chrom. B, 2002, 769, 235 .

[123] Zheng, Y; Qiu, Y.; Fu Lu, M.; Hoffman, D.; Reiland, T.L. Int. J. Pharm., 1999, 185, 83

[124] Haviv, F.; Fitzpatrick, T.D.; Nichols, C.J.; Swenson, R.E.; Bush. E.N. Diaz, G.: Nguyen, A: Nellans, H.N.; Hoffman, D.J. Ghanbari, H.; Johnson, E.S.; Love, S.; Cybuleki, V.; Greer, J. J. Med. Chem. 1992, 35, 3890.

[125] Bi, M.; Singh, J. Int. J. Pharm., 1998, 175, 269

[126] Raiman, J.; Koljonen, M.; Huikko, K.; Kostiainen, R.; Hirvonen, J. Eur. J. Pharm. Sci., 2004, 21, 371 .

[127] Yang, X; Rojanasakul, Y.; Wang, L.; Ma, J.Y.C.; Ma, K.H. Pharm. Res., 1998, /5, 1480 .
[128] Yang, X: Ma, J.K.A: Malanga, C. J; Rojanasakul, Y. Int. J. Pharm., 2000, 195, 93

[129] Bajusz, S.; Kovács, M.; Gazdag, M.; Bokser, L.; Karashima, T.; Csernus, V.J.; Janáky, T:; Guoth, J.; Schally, A.V. Proc. Natl. Acad. Sci. USA, 1988, 85, 1637

[130] Schwahn, M.; Schupke, H.; Gasparic, A.; Krone, D.; Peter, G. Hempel, R.; Kronbach, T; Locher, M.; Jahn, W.; Engel, J. Drug Metab. Dispos., 2000, 28, 10

[13I] Brudel, M. Kertscher, U.; Berger, H.; Mehlis, B. J. Chromat. A. 1994, 66I, 55 . 